\title{
Gradients of Primary and Secondary Infection by Monilinia vaccinii-corymbosi from Point Sources of Ascospores and Conidia
}

\author{
K. D. Cox and H. Scherm, Department of Plant Pathology, University of Georgia, Athens 30602
}

\begin{abstract}
Cox, K. D., and Scherm, H. 2001. Gradients of primary and secondary infection by Monilinia vaccinii-corymbosi from point sources of ascospores and conidia. Plant Dis. 85:955-959.

Spread of mummy berry disease of blueberry, caused by Monilinia vaccinii-corymbosi, occurs in two discrete monocycles; primary infection by ascospores results in shoot blight, while secondary infection of open flowers by conidia leads to fruit mummification. Gradients of primary and secondary infection from point sources of ascospores and conidia placed in separate plant rows were recorded in each of 2 years at two sites with no history of the disease. Primary infection gradients were longer downwind than upwind, with $95 \%$ of blighted shoots occurring within $30 \mathrm{~m}$ of the ascospore point source. This observation, along with a positive correlation $(r$ $=0.852, P=0.0072, n=8$ ) between the distance over which shoot blight occurred and wind speed parallel to the row, supports the role of wind as a key factor in ascospore dispersal. By contrast, secondary infection gradients were shorter downwind and longer upwind, with $95 \%$ of infected fruit occurring within $20 \mathrm{~m}$ of the conidial point source. The shorter downwind spread of secondary infection, along with a nonsignificant correlation $(r=-0.649, P=0.0812, n=8)$ between the distance over which infected fruit occurred and wind speed, suggests that factors other than wind are important in the transfer of conidia to open flowers; this could include conidial dispersal by bee pollinators, which have been shown previously to forage primarily upwind. Exponential and Pareto cumulative distribution functions were fitted to cumulative counts of blighted shoots and infected fruit to model spread of primary and secondary infection. The Pareto model, which is characterized by a longer tail and predicts more infection farther from the inoculum source, better fits the observed disease gradients in most cases.
\end{abstract}

Additional keywords: epidemiology, Vaccinium ashei

The discomycete Monilinia vacciniicorymbosi (Reade) Honey causes mummy berry disease, a major problem in the production of blueberries (Vaccinium spp.) in North America $(1,12,26)$. The most conspicuous symptom of the disease is the conversion of infected fruit into pseudosclerotia (mummies) that drop to the ground before or at harvest and serve as oversummering and overwintering structures $(1,12,33)$. Carpogenic germination of pseudosclerotia in late winter/early spring gives rise to apothecia, the only source of primary inoculum. Ascospores, liberated from apothecia primarily during periods of high humidity (24), infect expanding vegetative host tissues $(11,15)$, resulting in a shoot and leaf blight (primary infection). Grayish masses of conidia soon are produced on blighted shoots. Conidia are unable to cause further infection of vegetative tissues but are responsible for infection of the fruit (secondary infection) via the stigma and style of open flowers, with subsequent colonization of the locules

Corresponding author: H. Scherm

E-mail: scherm@uga.edu

Accepted for publication 14 May 2001.

Publication no. D-2001-0619-01R

(C) 2001 The American Phytopathological Society within the developing fruit $(18,28,33)$. This leads to the formation of pseudosclerotia as the fruit mature.

Given the importance of both ascospores and conidia in the mummy berry disease cycle, knowledge of dispersal patterns of the two spore types is important for assessing potential infection from outside inoculum sources, e.g., nearby affected blueberry plantings or native Vaccinium spp. growing near commercial plantings. Field observations indicate that pseudosclerotia are present in low numbers in most commercial blueberry plantings in Georgia $(\mathrm{H}$. Scherm, unpublished), suggesting that outside inoculum sources may be important. Batra (1) reported that ascospore longevity is greater than that of conidia, indicating that the former are better adapted to long-distance transport. However, the dispersal ranges of ascospores and conidia of M. vaccinii-corymbosi and the distance within which affected plantings or native Vaccinium spp. pose a risk to other blueberry plantings are not known.

Disease spread from ascospore inoculum has been well documented for other discomycete plant pathogens, including Sclerotinia sclerotiorum, a close relative of $M$. vaccinii-corymbosi that causes stem rot (white mold) of soybean. Wegulo et al. (30) studied spread from area, point, and strip sources of inoculum. Disease gradients from point sources (apothecia pro- duced on sclerotia) suggested that most ascospores were deposited within $3 \mathrm{~m}$ of the source. In an experiment involving dispersal from an area source (apothecia produced in a neighboring field), the highest stem rot incidence occurred within 15 $\mathrm{m}$ of the source, with disease incidence decreasing exponentially up to $45 \mathrm{~m}$ from the source. This agrees with other studies reporting that most ascospores are deposited close to the apothecia in which they are produced $(10,14)$. Nevertheless, ascospores, like other wind-dispersed spores, potentially can travel long distances, often well in excess of $100 \mathrm{~m}$ (14).

Disease gradients resulting from conidial infection have been quantified in various fungal pathosystems that depend on wind (14), rain splash $(7,21)$, or winddriven rain $(6,22)$ for dispersal. Although all these factors have been hypothesized to play roles for $M$. vaccinii-corymbosi (2), dispersal of conidia in this species may be affected more by the presence and activity of insect pollinators. Woronin (33), in the first detailed study of $M$. vacciniicorymbosi, observed that infected vegetative tissues bearing conidia had a pleasant, almond-like odor. He hypothesized that this may aid in recruiting pollinators to assist in the transfer of conidia from blighted shoots to the stigmatic surfaces of open flowers, a phenomenon demonstrated conclusively by Batra and Batra (3) almost one century later. Nevertheless, the importance of insect-mediated dispersal relative to that of wind or rain splash has not been clarified for conidia of $M$. vacciniicorymbosi. The study of gradients of secondary infection from point sources of conidial inoculum could cast light on the contribution to disease spread of different dispersal mechanisms.

The objective of this study was to quantify gradients of primary and secondary infection from point sources of ascospores and conidia of $M$. vaccinii-corymbosi. Information derived from this study could be used to model spread of primary and secondary infection. It could also help clarify the contribution to secondary disease spread by different conidial dispersal mechanisms. An abstract reporting preliminary results has been published (4).

\section{MATERIALS AND METHODS}

General. Field experiments were carried out in 2 years at two sites that had no history of mummy berry disease. At each site, disease gradients were recorded in two separate plant rows. In one row, primary 
infection gradients based on counts of blighted shoots from an ascospore point source were determined; in the second row, secondary infection gradients based on counts of infected fruit from a conidial point source were assessed. The secondary infection row was located upwind of the primary infection row to minimize risk of contamination by conidia produced in the primary row.

Experiments with potted plants. Rows of 1- or 2-year-old rabbiteye blueberry plants ( $V$. ashei cvs. Tifblue and Brightwell) grown in 7.6-liter plastic pots and between 0.8 and $1.1 \mathrm{~m}$ in height were placed on a level grass surface at the University of Georgia Crop Science Farm in Oconee County in late winter of 1999 and 2000. Two cultivars were used to ensure fruit set via cross-pollination and to establish different vegetative bud break and flowering dates, thereby increasing the chance of infection in at least one of the two cultivars. The primary infection row consisted of 85 plants of each cultivar placed side-by-side at a distance of $0.9 \mathrm{~m}$; within-row spacing was $1 \mathrm{~m}$. A similar arrangement comprising 65 plants of each cultivar was designated as the secondary infection row. The secondary row was shorter than the primary row because it was hypothesized that dispersal of conidia occurs over a shorter distance than that of ascospores. The rows were oriented parallel to the prevailing westerly winds as determined from data recorded at an agrometeorological weather station located on-site (13).

In early March in both years, when average vegetative bud development was between stages 3 (late green tip) and 4 (leaves beginning to unfold) (20), an ascospore point source was placed in the primary infection row, with 31 plants located upwind and 54 located downwind from the inoculum source. The inoculum source consisted of newly emerged apothecia from 30 pseudosclerotia placed on moist sand in a 0.5-liter plastic pot (27); inoculum placement was off-center to allow for a longer distance in the downwind direction over which to observe ascospore infec-
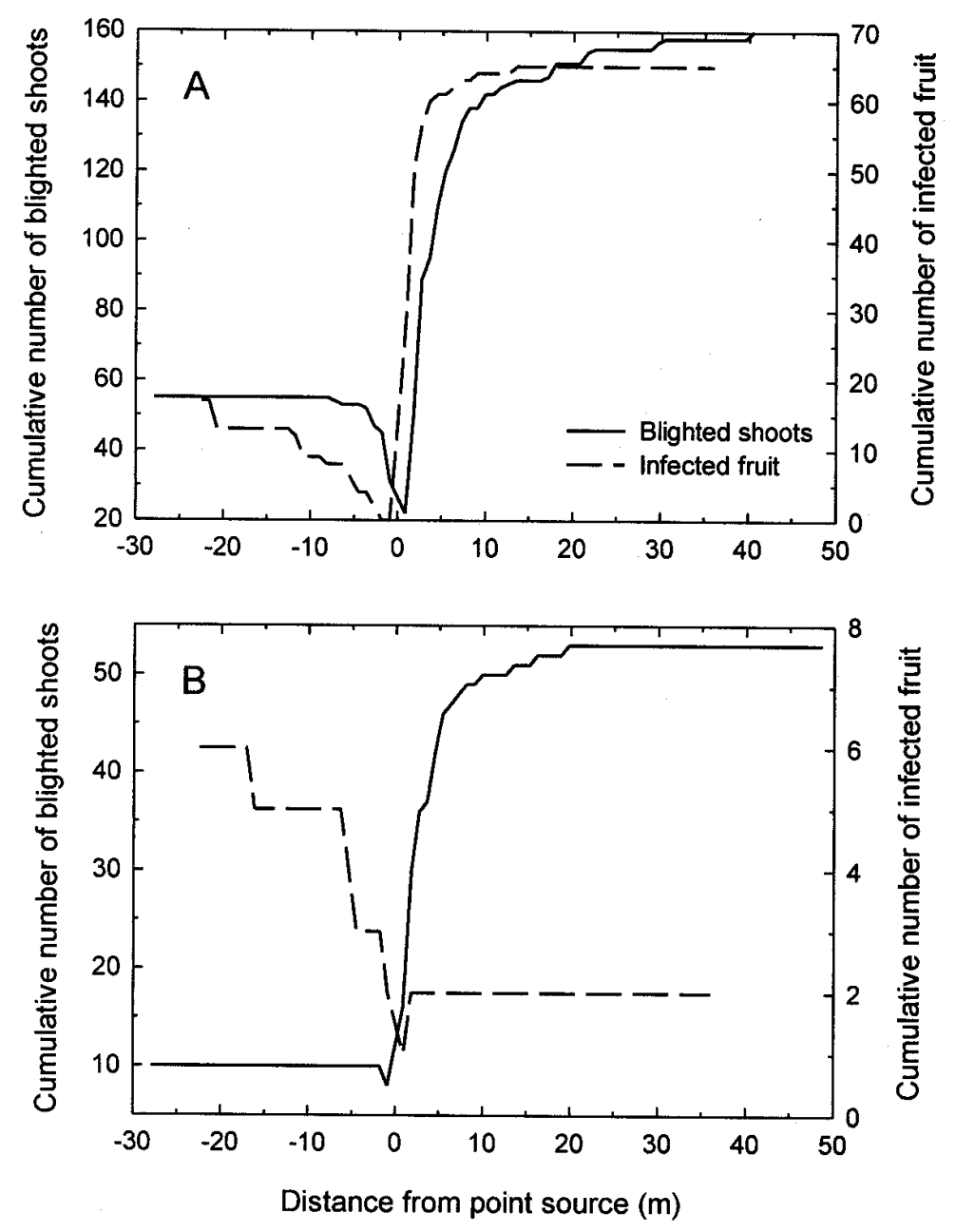

Fig. 1. Cumulative counts of blighted shoots (primary infection) and mummified fruit (secondary infection) caused by Monilinia vaccinii-corymbosi in separate rows of potted rabbiteye blueberry plants containing point sources of ascospores or conidia. Disease assessments were made, $\mathbf{A}$, in cv. Tifblue in 1999 and B, in cv. Brightwell in 2000. Negative and positive distances denote, respectively, directions up- and downwind from the inoculum point source.

tion. In both years, viable apothecia were present for ca. 2 weeks.

In late March or early April, when average flower bud development was at stage 5 (individual flowers separated but corollas still closed) (29), a conidial point source was placed in the secondary infection row, with 25 plants located upwind and 40 located downwind of the inoculum source. The inoculum source consisted of four potted blueberry plants with blighted, conidia-bearing shoots. In both years, the inoculum source remained in the field throughout bloom.

Experiments in mature planting. The second site comprised four 40-m-long blocks, each with eight rows of mature blueberry plants of different species and cultivars located at the USDA Southeastern Fruit and Tree Nut Research Laboratory in Peach County. The planting had been established in 1986 and was oriented in north-south direction. Plants were 1.9 to $2.6 \mathrm{~m}$ in height, and row spacing was $7 \mathrm{~m}$. In 1999, single rows of cv. Tifblue in blocks 1 (downwind) and 4 (upwind), ca. $80 \mathrm{~m}$ apart, were used as primary and secondary infection rows, respectively. In 2000, single rows of cv. Climax in block 1 and of cv. Baldwin in block 4 were used. Different cultivars were used in 2000 to maximize the distance from the experimental rows used in the previous year. In addition, pseudosclerotia formed during the 1999 experiment were collected from the plants and the ground underneath plants to prevent carryover of primary inoculum into the 2000 season.

In early March in both years, when average vegetative bud development was between stages 4 and 5 (mouse-ear stage), an ascospore point source (30 pseudosclerotia with apothecia maintained on moist sand as described previously) was placed in the primary infection row. In both years, viable apothecia were present for ca. 2 weeks.

In late March or early April, when average flower bud development was between stages 5 and 6 (corollas completely expanded and open), a conidial point source (four potted plants with blighted shoots as described previously) was placed in the secondary infection row. The inoculum source remained in the field throughout bloom.

Disease assessment. At weekly intervals in March and April, the number of blighted shoots per plant was counted in the primary infection rows. In the secondary infection rows in the potted plant experiment, the number of infected fruit per plant was assessed when fruit had begun to mature in July each year. All fruit were harvested from these plants and dissected to confirm presence of $M$. vaccinii-corymbosi (25). In the experiments involving the mature plants, secondary infection rows were assessed twice during fruit maturation to determine the number of infected fruit. 
Symptomatic fruit were collected from the ground underneath each plant and dissected to confirm presence of $M$. vacciniicorymbosi (25).

Disease gradients and relationship to wind. Gradients of primary infection, showing the cumulative number of blighted shoots per plant for increasing distances up- and downwind from the ascospore point source, were plotted for the primary infection rows. Distances from the point source at which the cumulative total of blighted shoots reached 95\% (95th percentile) were calculated for each row in upand downwind directions. These distances were then plotted against mean seasonal corrected wind speed to evaluate the influence of wind on spread of primary infection. For each day, corrected up- and downwind wind speeds were calculated based on mean daily wind speed and mean daily wind direction, both recorded by onsite agrometeorological stations (13), using a trigonometric relationship to consider only the wind vectors parallel to each row. Seasonal means were then computed by averaging daily means for the period when viable apothecia were present in the planting but before host leaves had reached stage 6 (leaves fully expanded); susceptibility to ascospore infection has been shown to decrease considerably after leaves have expanded $(11,15)$.

Similar calculations relating the distances from the conidial point source at which the cumulative totals of infected fruit reached $95 \%$ were made separately in up- and downwind directions to evaluate the influence of wind on disease spread in each secondary infection row. In this analysis, mean seasonal corrected wind speeds were computed for the period when plants with blighted shoots were placed in the planting until end of bloom.

Gradient models. Two disease gradient models, based on the exponential and Pareto cumulative distribution functions (19), were fitted to cumulative counts of blighted shoots or infected fruit in each row. The two models were selected to represent different patterns in the tail end of the distribution, with the tail of the expo- nential model being shorter and predicting more infection closer to the source than that of the Pareto model $(19,23)$. Both models were fitted separately in up- and
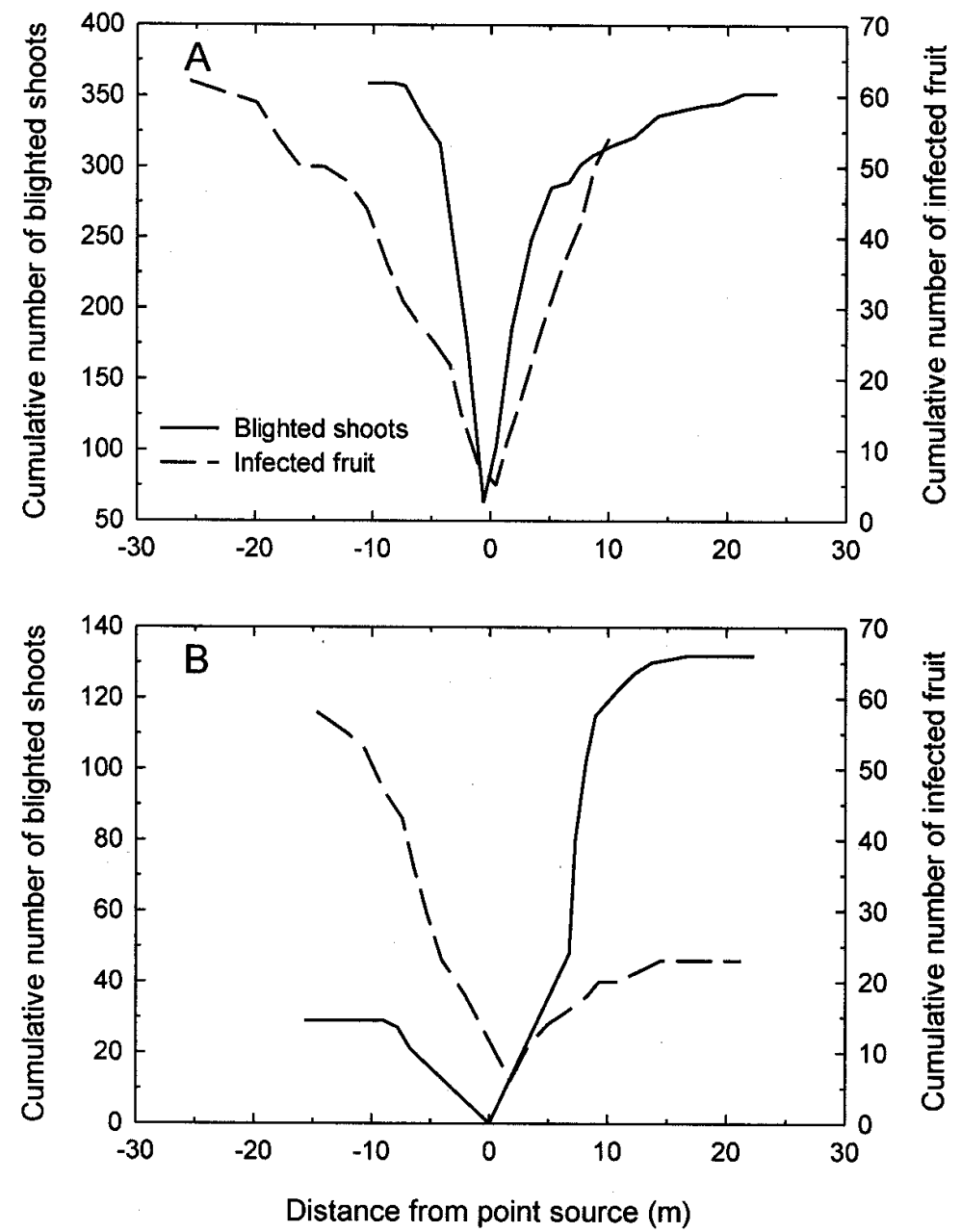

Fig. 2. Cumulative counts of blighted shoots (primary infection) and mummified fruit (secondary infection) caused by Monilinia vaccinii-corymbosi in separate rows of mature rabbiteye blueberry plants containing point sources of ascospores or conidia. A, In 1999, both primary and secondary infection were monitored in cv. Tifblue. B, In 2000, primary and secondary infection were monitored in cvs. Climax and Baldwin, respectively. Negative and positive distances denote, respectively, directions up- and downwind from the inoculum point source.

Table 1. Distance from inoculum point sources containing 95\% of blighted shoots (primary infection by Monilinia vaccinii-corymbosi) and mummified fruit (secondary infection) in rows of rabbiteye blueberries in up- and downwind directions ${ }^{\mathrm{a}}$

\begin{tabular}{|c|c|c|c|c|c|c|c|c|c|c|c|c|}
\hline \multirow[b]{3}{*}{ Experiment } & \multirow[b]{3}{*}{ Year } & \multirow[b]{3}{*}{ Direction } & & & \multicolumn{8}{|c|}{ Predicted distance $(m)^{b}$} \\
\hline & & & \multicolumn{2}{|c|}{ Observed distance (m) } & \multicolumn{4}{|c|}{ Exponential model } & \multicolumn{4}{|c|}{ Pareto model } \\
\hline & & & Blight & Mummies & Blight & $R^{2}$ & Mummies & $R^{2}$ & Blight & $R^{2}$ & Mummies & $R^{2}$ \\
\hline \multirow[t]{4}{*}{ Potted plants ${ }^{\mathrm{c}}$} & 1999 & Upwind & 3.8 & 21.4 & 3.4 & 0.97 & 33.2 & 0.93 & 4.2 & 0.99 & 33.2 & 0.93 \\
\hline & & Downwind & 30.0 & 6.1 & 14.7 & 0.90 & 4.1 & 0.77 & 26.3 & 0.97 & 4.7 & 0.91 \\
\hline & 2000 & Upwind & 1.6 & 16.9 & $\ldots^{\mathrm{d}}$ & & 14.6 & 0.85 & $\ldots$ & & 20.0 & 0.88 \\
\hline & & Downwind & 12.9 & 1.7 & 8.1 & 0.97 & 1.0 & & 10.6 & 0.99 & 20.0 & \\
\hline \multirow[t]{4}{*}{ Mature plants $\mathrm{e}^{\mathrm{e}}$} & 1999 & Upwind & 6.2 & 19.8 & 7.4 & 0.98 & 26.5 & 0.98 & 7.4 & 0.98 & 26.5 & 0.98 \\
\hline & & Downwind & 14.0 & 9.2 & 9.2 & 0.91 & 15.3 & 0.94 & 16.3 & 0.98 & 15.3 & 0.94 \\
\hline & 2000 & Upwind & 8.1 & 12.2 & 1.5 & 0.51 & 17.6 & 0.92 & 4.9 & 0.81 & 17.6 & 0.92 \\
\hline & & Downwind & 11.8 & 13.1 & 8.9 & 0.99 & 15.4 & 0.98 & 9.8 & 0.99 & 15.4 & 0.98 \\
\hline
\end{tabular}

${ }^{a}$ Spread of primary infection from point sources of ascospores (apothecia on pseudosclerotia) and of secondary infection from point sources of conidia (blighted shoots on potted blueberry plants) was monitored in separate rows.

b Models were fitted to observed cumulative counts of blighted shoots or infected fruit, and the distance from the point source containing $95 \%$ of the two symptom types was calculated.

${ }^{c}$ Disease assessments were made in cv. Tifblue in 1999 and in cv. Brightwell in 2000.

${ }^{\mathrm{d}}$ Disease incidence in these directions was too low to fit the models.

e In 1999, both primary and secondary infection were monitored in cv. Tifblue; in 2000, primary and secondary infection were monitored in cvs. Climax and Baldwin, respectively. 
downwind directions using SigmaPlot software (version 6.00; SPSS Science Inc., Chicago, IL).

\section{RESULTS AND DISCUSSION}

Symptoms of primary and secondary infection developed at both locations in both years. In potted plants, shoot blight incidence attained maxima of 39 and 16 blighted shoots per plant in 1999 and 2000 , respectively. Maximum incidence of secondary infection was 28 (1999) and 2 (2000) infected fruit per plant. In mature plants, the numbers of blighted shoots and infected fruit were higher on a per-plant basis than in the potted plants, presumably because of their greater numbers of leaves and flowers. Similarly to potted plants, disease incidence was lower in 2000 than in 1999, most likely due to springtime drought conditions in conjunction with earlier development of leaf and flower buds, which resulted in a lower proportion of susceptible tissues available while inoculum sources were present (data not shown).

Disease gradients resulting from primary infection were longer downwind and shorter upwind, with $95 \%$ of blighted shoots occurring within 30.0 (1999) and 12.9 (2000) $\mathrm{m}$ downwind and 3.8 (1999) and 1.6 (2000) $\mathrm{m}$ upwind of the ascospore point source in potted plants (Fig. 1; Table 1). In mature plants, distances within which $95 \%$ of blighted shoots occurred were within a similar range, and the pattern of longer primary disease gradients downwind also was observed in both years (Fig. 2; Table 1). Wind strongly influenced spread of primary infection; across both years and sites, the distance from the ascospore point source containing $95 \%$ of blighted shoots was positively correlated $(r=0.852, P=0.0072, n=8)$ with mean seasonal corrected wind speed (Fig. 3A).
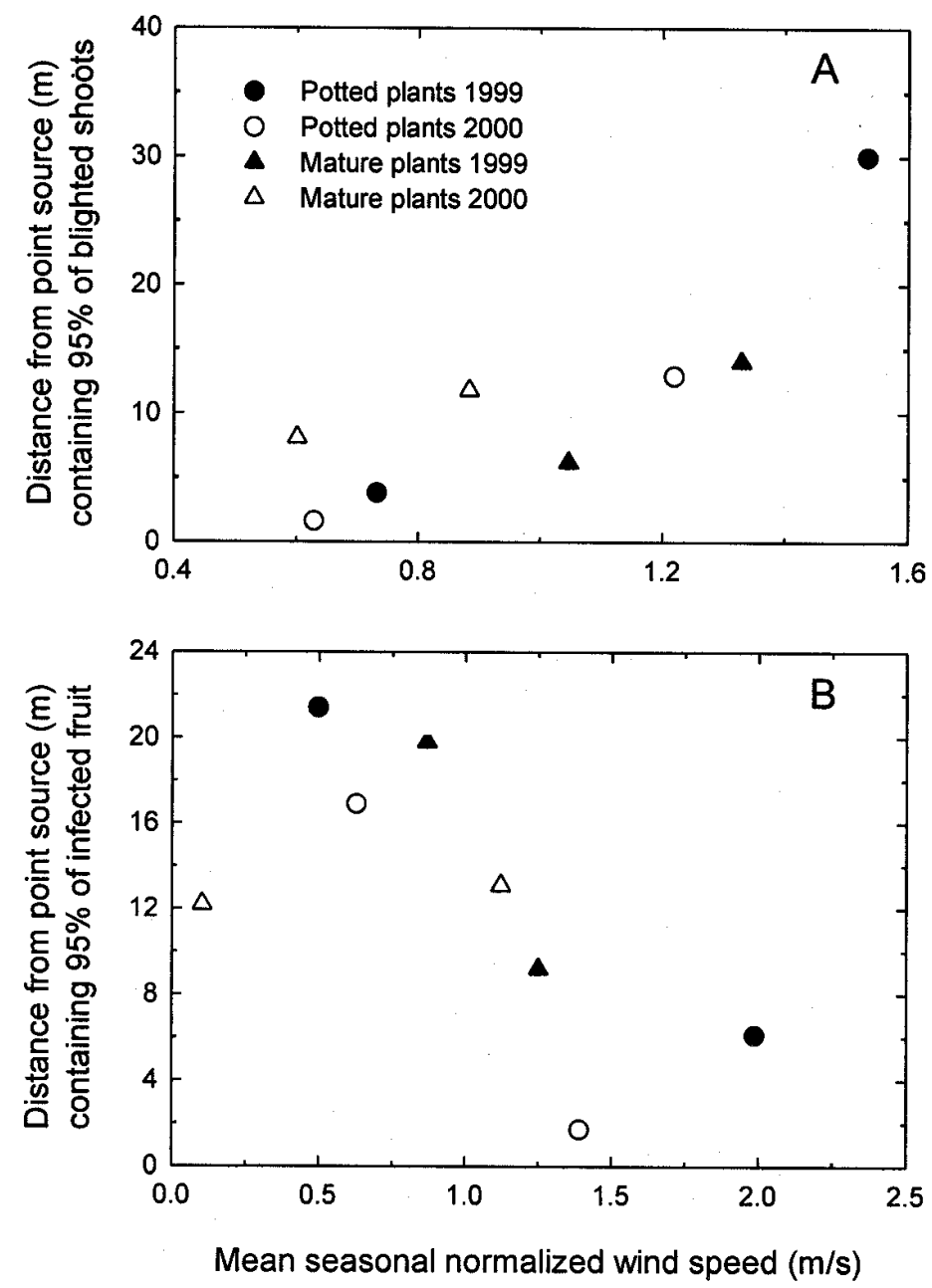

Fig. 3. Distance from inoculum point sources containing $95 \%$ of blighted shoots (primary infection; A) or mummified fruit (secondary infection; B) caused by Monilinia vaccinii-corymbosi in rows of rabbiteye blueberry in relation to mean seasonal corrected wind speed. Corrected up- and downwind wind speeds were calculated based on mean daily wind speed and mean daily wind direction using a trigonometric relationship to consider only the wind vectors parallel to the blueberry rows. Seasonal means of corrected wind speed were computed by averaging daily means for the period when inoculum was present and when host tissues were susceptible. There are two data points for each location and year, one each in up- and downwind directions. Correlation coefficients in $\mathbf{A}$ and $\mathbf{B}$ are $r=0.852$ $(P=0.0072)$ and $r=-0.649(P=0.0812)$, respectively.
Disease gradients resulting from secondary infection were shorter downwind and longer upwind, with $95 \%$ of infected fruit occurring within 21.4 (1999) and 16.9 (2000) $\mathrm{m}$ upwind and 6.1 (1999) and 1.7 (2000) $\mathrm{m}$ downwind of the conidial point source in potted plants (Fig. 1; Table 1). In mature plants, a similar pattern of shorter secondary disease gradients downwind generally was observed in both years (Fig. 2; Table 1). Wind only weakly affected secondary infection gradients; across both years and sites, the distance from the conidial point source containing $95 \%$ of infected fruit was not significantly correlated with mean seasonal corrected wind speed. There was, however, a trend $(r=-0.649, P$ $=0.0812, n=8$ ) for the distance from the conidial point source containing $95 \%$ of infected fruit to decrease with increasing wind speed (Fig. 3B).

Several conclusions can be drawn from the results on disease gradients in relation to wind. The observation that gradients of primary infection were longer downwind and shorter upwind of the ascospore point source supports the role of wind as a key factor in ascospore dispersal. This is further supported by the positive relationship between the distance over which shoot blight occurred and corrected wind speed. These observations are not surprising, given that ascospores generally are considered wind-dispersed based on their size and liberation patterns $(16,17)$.

By contrast, gradients of secondary infection generally were shorter downwind and longer upwind of the conidial point source, suggesting a limited role of wind in dispersal. The negative association between corrected wind speed and distance over which fruit infection occurred, albeit not statistically significant, further supports this idea. Batra and Batra (3) presented evidence for a key role of bee pollinators in dispersal of conidia of $M$. vaccinii-corymbosi from blighted shoots to flowers. They demonstrated that conidiabearing leaf tissue contained free sugars and reflected ultraviolet light similarly to blueberry floral calyces, thereby effectively attracting pollinators. They further documented pollinators sampling conidial chains on infected leaves, resulting in the presence of conidia on their mouthparts. A considerable reduction in the incidence of fruit infection (from 63 to $10 \%$ ) was observed in the same study when pollinators were excluded from flowers (3). Although no data on pollinator activity were collected in the present study, a key role of bee pollinators in conidial dispersal, as proposed by Batra and Batra (3), along with evidence for enhanced upwind foraging activity of bees as presented in studies on bee behavior $(5,8,31,32)$, could explain the longer upwind gradients observed with secondary infection.

Both gradient models showed a good fit to cumulative counts of blighted shoots or 
infected fruit across years and sites. In most cases, the Pareto cumulative distribution function fit the observed disease gradients somewhat better than the exponential model, based on $R^{2}$ values and similarity of predicted and observed distances containing $95 \%$ of blighted shoots or infected fruit (Table 1). In general, the two models predict that $95 \%$ of both primary and secondary infection occurs within 20 to $30 \mathrm{~m}$ of the point source. The better fit of the Pareto model suggests, however, that low levels of infection are likely to occur much farther away from the source because of the relatively long tail of this distribution. Wegulo et al. (30) observed that while most ascospores of $S$. sclerotiorum were deposited a few meters from inoculum point sources, some infection could be detected up to $80 \mathrm{~m}$ from area and strip sources. They concluded that many point sources distributed over a larger area increased the potential for longdistance dispersal. Similarly, Gregory (9) demonstrated that long-distance transport of wind-dispersed inoculum is conceivable in cases where steep spore dispersal gradients might otherwise suggest negligible infection at a relatively short distance from the source. He further noted that meteorological conditions that result in steep dispersal gradients are the same that allow for a larger escape fraction of dispersed spores that would then be available for longdistance transport. Thus, despite the relatively short disease gradients observed in this study, long-distance spread should not be discounted in the mummy berry pathosystem.

\section{ACKNOWLEDGMENTS}

This work was supported by Hatch Act and State of Georgia funds. We thank A. Amis for plot maintenance and C. Mims, J. Williams-Woodward, and A. Savelle for reviewing an earlier version of the manuscript.

\section{LITERATURE CITED}

1. Batra, L. R. 1983. Monilinia vacciniicorymbosi (Sclerotiniaceae): Its biology on blueberry and comparison with related species. Mycologia 75:131-152.

2. Batra, L. R. 1991. World Species of Monilinia (Fungi): Their Ecology, Biosystematics and Control. Mycological Memoir No. 16, J. Cramer, Berlin.

3. Batra, L. R., and Batra, S. W. T. 1985. Floral mimicry induced by mummy-berry fungus exploits host's pollinators as vectors. Science 228:1011-1012.

4. Cox, K. D., and Scherm, H. 2000. Primary and secondary disease gradients of Monilinia vaccinii-corymbosi from point sources of inoculum. (Abstr.) Phytopathology 90:S125.

5. Dag, A., and Eisikowitch, D. 1995. The influence of hive location on honeybee foraging activity and fruit set in melons grown in plastic greenhouses. Apidologie 26:511-519.

6. Ferrandino, F. J., and Elmer, W. H. 1996. Septoria leaf spot density on trap plants exposed at varying distances from infected tomatoes. Plant Dis. 80:1059-1062.

7. Fitt, B. D. L., McCartney, H. A., and Walklate, P. J. 1989. The role of rain in dispersal of pathogen inoculum. Annu. Rev. Phytopathol. 27:241-270.

8. Friesen, L. J. 1973. The search dynamics of recruited honeybees. Biol. Bull. 144:107-131.

9. Gregory, P. H. 1981. Disease gradients of windborne plant pathogens: Interpretation and misinterpretation. Pages 107-117 in: Advancing Frontiers of Mycology and Plant Pathology. K. S. Bilgrami, R. S. Misra, and P. C. Misra, eds. Today and Tomorrow's Printers and Publishers, New Delhi.

10. Hartil, W. F. T. 1980. Aerobiology of Sclerotinia sclerotiorum and Botrytis cinerea spores in New Zealand tobacco crops. N.Z. J. Agric. Res. 23:259-262.

11. Hildebrand, P. D., and Braun, P. G. 1991. Factors affecting infection of lowbush blueberry by ascospores of Monilinia vacciniicorymbosi. Can. J. Plant Pathol. 13:232-240.

12. Honey, E. E. 1936. North American species of Monilinia. I. Occurrence, grouping, and lifehistories. Am. J. Bot. 23:100-106.

13. Hoogenboom, G. 1996. The Georgia Automated Environmental Network. Pages 343346 in: Preprints, 22nd Conf. Agric. Forest Meteorol. \& 12th Conf. Biometeorol. Aerobiol. American Meteorological Society, Boston, MA.

14. Lacey, J. 1996. Spore dispersal - its role in ecology and disease: The British contribution to fungal aerobiology. Mycol. Res. 100:641660.

15. Lehman, J. S., and Oudemans, P. V. 1997. Phenology of the mummy berry fungus and its blueberry host: Implications for resistance breeding. Acta Hortic. 446:287-292.

16. McCartney, H. A., and Lacey, M. E. 1991. The relationship between the release of ascospores of Sclerotinia sclerotiorum, infection and disease in sunflower plots in the United Kingdom. Grana 30:486-492.

17. McCartney, H. A., and Lacey, M. E. 1992. Release and dispersal of Sclerotinia ascospores in relation to infection. Brighton Crop Prot. Conf.: Pests Dis. - 1992 1:109-116.

18. Milholland, R. D. 1977. Sclerotium germination and histopathology of Monilinia vacciniicorymbosi on highbush blueberry. Phytopathology 67:848-853.

19. Minogue, K. P. 1989. Diffusion and spatial probability models for disease spread. Pages 127-143 in: Spatial Components of Plant Disease Epidemics. M. J. Jeger, ed. Prentice Hall, Englewood Cliffs, NJ.

20. NeSmith, D. S., Krewer, G., and Williamson, J. G. 1998. A leaf bud scale for rabbiteye blueberry. HortScience 33:757.

21. Parker, S. K., Gleason, M. L., and Nutter, F. W., Jr. 1995. Influence of rain events on spatial distribution of Septoria leaf spot of tomato. Plant Dis. 79:148-152.

22. Parker, S. K., Nutter, F. W., Jr., and Gleason, M. L. 1997. Directional spread of Septoria leaf spot in tomato rows. Plant Dis. 81:272 276.

23. Portnoy, S., and Wilson, M. F. 1993. Seed dispersal curves: The behavior of the tail of the distribution. Evol. Ecol. 7:25-44.

24. Ramsdell, D. C., Nelson, J. W., and Myers, R. 1974. An epidemiological study of mummy berry disease of highbush blueberry. Phytopathology 64:222-228.

25. Scherm, H., and Copes, W. E. 1999. Evaluation of methods to detect fruit infected by Monilinia vaccinii-corymbosi in mechanically harvested rabbiteye blueberry. Plant Dis. 83:799-805.

26. Scherm, H., Horton, D. L., NeSmith, D. S., Krewer, G., and Savelle, A. T. 1999. Georgia blueberry pest management survey. Pages 3745 in: Blueberry Research at the University of Georgia: 1999 Annual Research Update. D. S. NeSmith, ed. Research Report 662, University of Georgia, College of Agricultural and Environmental Sciences, Athens.

27. Scherm, H., Savelle, A. T., and Pusey, P. L. 2001. Interactions between chill-hours and degree-days affect carpogenic germination in Monilinia vaccinii-corymbosi. Phytopathology 91:77-83.

28. Shinners, T. C., and Olson, A. R. 1996. The gynoecial infection pathway of Monilinia vaccinii-corymbosi in lowbush blueberry (Vaccinium angustifolium). Can. J. Plant Sci. 76:493-497.

29. Spiers, J. M. 1978. Effect of stage of bud development on cold injury in rabbiteye blueberry. J. Am. Soc. Hortic. Sci. 103:452-455.

30. Wegulo, S. N., Sun, P., Martinson, C. A., and Yang, X. B. 2000. Spread of Sclerotinia stem rot of soybean from area and point sources of apothecial inoculum. Can. J. Plant Sci. 80:389-402.

31. Wenner, A. M. 1963. The flight speed of honeybees: A quantitative approach. J. Apicultural Res. 2:25-32.

32. Woodell, S. R. J. 1978. Directionality in bumblebees in relation to environmental factors. Pages 31-39 in: The Pollination of Flowers by Insects. A. J. Richard, ed. Linnean Society Symposium Series No. 6, Academic Press, London.

33. Woronin, M. 1888. Über die Sclerotienkrankheit der Vaccinieen-Beeren. Mémoires de l'Académie Impériale des Sciences de St.Pétersbourg (VIIe Série) 36:1-49. 